\title{
КОМПОЗИЦИОННЫЕ РАСТИТЕЛЬНЫЕ ЭКСТРАКТЫ КАК ДЕТОКСИКАНТЫ СВИНЦА И КАДМИЯ В МОДЕЛЬНОМ ЭКСПЕРИМЕНТЕ
}

Ю.И. Коваль, кандидат биологических наук, доцент

И.В. Васильцова, кандидат биологических наук, доцент

Т.И. Бокова, доктор биологических наук, профессор

Новосибирский государственный аграрный университет

E-mail: chemi_ngau@mail.ru

Ключевые слова: антропогенные загрязнители, кадмий, свинец, композиционные растительные экстракты, прополис, листья березы, хвоя сосны.

Реферат. Приводятся результаты изучения особенностей воздействия композииионных водно-спиртовых экстрактов прополиса (Propolis), листьев березы (Betula pendula) и хвои сосны (Pinus sylvestris L.) на организм лабораторных крыс в условиях кратковременной интоксикаиии тяжельми металлами в дозировках 15 мг свинца и 1,5 мг кадмия на 1 кг живой массы. В ходе исследований установлено, что воздействие тяжельх металлов на организм лабораторных животных имеет избирательный характер - основным «депо» свинца явилась костная ткань, а кадмия - почки и печень. Добавление к раииону крыс 0,5 мл водно-спиртовых экстрактов из лекарственного сырья в качестве детоксикантов вызвало снижение уровня свинца в организме животных до 17,50, кадмия - до 12,76 раза. Наибольшую детоксикаиионную способность в отночении ионов свинца и кадмия проявил экстракт листьев березы и хвои сосны (1 : 1, композиция 2). Под влиянием повышенных доз свинца и кадмия у лабораторных животных наблюдалось уменьшение живой массы на 10,22 \%, показателя среднесуточного прироста - на 30,48, содержания общего белка в сыворотке - на 8,22, альбумина - на 17,14, мочевины - на 17,72, глюкозы - на 42,9\%; увеличение конщентрации холестерина, кальиия и фосфора на 17,12; 26,13 и 38,43\% соответственно. Водно-спиртовые экстракты частично или полностью нормализовали биохимические показатели сыворотки крови крыс. Таким образом, проведенные исследования показали, что композиционные экстракты на основе прополиса, листьев березы и хвои сосны могут являться основой для разработки эффективного растительного препарата, используемого для профилактики и лечения животных от интоксикации солями тяжелых металлов.

В настоящее время загрязнение биосферы тяжелыми металлами представляет серьезную проблему для окружающей среды и здоровья человека.

Природное растительное сырье богато биологически активными веществами, содержащими в своем составе большое количество функциональных групп (-OH, $-\mathrm{COOH}$ и др.). Наличие функциональных групп обеспечивает соединениям, содержащимся в данном сырье, способность связывать токсиканты и выводить их из организма [1].

Прополис - смолоподобное вещество, собираемое пчелами с поверхностей листьев, с примесью нектара и пыльцы, переработанной энзимами желез пчёл. Чистый, свежий прополис на вкус горьковато-острый, с терпким запахом [2].

Химический состав прополиса изучен относительно хорошо, определено более 180 соединений. Прополис богат фитонцидами растений, в нём много органических кислот, терпеновых соединений (50-55 \% растительных смол, 8-10 \% летучих веществ, около 30 \% воска, терпеновые кислоты). Прополис содержит смолистые кислоты и спирты, артипиллин, фенолы, дубильные вещества, бальзамы (коричный спирт, коричная кислота), воск, эфирные масла, флавоноиды. Типичные составляющие прополиса: акацетин, апигенин, альфа-ацетоокси-бетуленол, кемпферид, рамноцитрин, эрманин. Прополис содержит более 50 органических компонентов и минеральных элементов (K, Ca, P, Na, Mg, S, Cl, Al, Va, Fe, Mn, Zn, Cu, Si, Sn, Se, Ag, $\mathrm{F}$, Со и др., в повышенных количествах - Zn и $\mathrm{Mn}$ ), витамины $\mathrm{B}_{1}, \mathrm{~B}_{2}, \mathrm{~B}_{6}, \mathrm{~A}, \mathrm{E}$, никотиновую, 
пантотеновую кислоты и др., 17 аминокислот (аспарагин, глутамин, триптофан, фенилаланин, лейцин, цистин, метионин, валин, гликокол, гистидин, аргинин, пролин, тирозин, треонин, аланин, лизин) [3-5].

В современной научной медицине прополис применяют очень широко. Из него готовятся различные лекарственные формы - масло, мази, настойки и экстракты. Прополис обладает антиоксидантными свойствами, которые связывают с наличием флавоноидов, установлены его антимикробные, антибактериальные, иммуномодулирующие свойства, усиливающиеся в сочетании с медом и этиловым спиртом $[6,7]$.

Экспериментальные исследования показали, что прополис защищает клетки печени от токсического воздействия хлорида ртути, почки - от поражения при кадмиевой интоксикации, репродуктивную систему - от токсического воздействия трифелтина хлорида; уменьшается токсическое воздействие на организм солей бериллия, кобальта [8-11].

В листьях березы (Betula pendula) содержатся флавоноиды $(2,77 \%)$, в том числе гиперозида - 0,77\%, авикулярина - 0,26, 3-дигалактозида мирицетина - 0,18, 3-глюкуронида кверцетина - 0,36, кверцитрина - 0,12\%, выявлены монотерпеновые глюкозиды бетулаальбозиды А и В, тритерпены - производные дамароланостана (бетулафолиентриол - 0,8 \% и бетулафолиентетрол и их эфиры), полипреноловые соединения (бетулапренол, бутапренол), а также 3- $\beta$-D-глюкозид 3,4-дигидроксипроприофенона, стерины, дубильные вещества пирокатехиновой группы (1,07-9 \%), горечи, кумарины (0,09-0,44 \%), антоцианы, смолы (бетулестер), бутиловый эфир бетулоретиновой кислоты, 8-10\% сахаров, инозит, горечи, аскорбиновая (до 2,8 \%) и никотиновая кислоты, никотинамид, каротин. Настой из свежих молодых листьев березы используют как мочегонное и потогонное средство при отеках, асците, болезнях почек, при авитаминозах, атеросклерозе, для повышения сопротивляемости организма и выведения из него токсинов [12-16].

В хвое сосны (Pinus silvestris) содержатся дубильные вещества (около 5 \%), эфирное масло (до $0,3 \%$ ), составными частями которого являются борнеол, борнил ацетат, кадинен, церратендиол; алкалоиды, смолы, жиры (около 3 \%), крахмал (около 20 \%), каротин, сахара, минеральные соли (особенно железа), до 300 мг\% витамина С, витамины К, Е (до 0,3 \%), флавоноиды - мирицитрин, токсифолин, кемпферол. Хвоя сосны обладает сильным противовоспалительным, иммуномодулирующим действием, дезинфицирующим свойством, ее применяют в лечении заболеваний лёгочной, сердечно-сосудистой систем, опорно-двигательного аппарата. При длительном применении хвоя способствует выводу из организма вредных веществ. Эфирное масло сосны обладает способностью справиться с возбудителями лёгочных инфекций, прекрасно очищает слизистую дыхательных путей [17-19].

Цель исследований - изучение особенностей воздействия композиционных водно-спиртовых экстрактов лекарственных растений и прополиса на организм лабораторных крыс в условиях кратковременной интоксикации свинцом и кадмием.

Задачи:

1. Установить особенности распределения антропогенных загрязнителей в органах и тканях крыс при их совместном введении в корм в концентрации 15 мг свинца $+1,5$ мг кадмия.

2. Выявить влияние водно-спиртовых экстрактов на аккумуляцию тяжелых металлов в организме лабораторных животных.

3. Изучить рост и развитие крыс на фоне нагрузки тяжелыми металлами и при использовании экстрактов на основе прополиса, листьев березы и хвои сосны.

4. Определить биохимические показатели крови при применении детоксикантов и без них на фоне интоксикации.

Исследования проводились на базе кафедры химии ФГБОУ ВО Новосибирский ГАУ в соответствии с открытой инициативной тематикой научно-исследовательских работ «Экологическая 
оценка лекарственных растений в Сибири и препаратов на их основе с целью использования для адаптации живых систем в условиях моделирования загрязнения среды тяжелыми металлами»» (регистрационный номер темы: АААА-А18-118030790007-0).

В качестве объектов исследования были выбраны композиционные водно-спиртовые экстракты прополиса (Propolis) и лекарственных растений - листьев березы (Betula pendula), хвои сосны (Pinus sylvestris), а также лабораторные крысы.

Приготовление экстрактов осуществлялось из аптечного лекарственного сырья с использованием $40 \%$-го раствора этанола, время извлечения биологически активных веществ составило 72 ч, соотношение «сырье : этанол» - $1: 20$.

В эксперименте использовали экстракты «прополис : листья березы : хвоя сосны» $(1: 1: 1$, композиция 1) и «листья березы : хвоя сосны» (1 : 1 , композиция 2$)$.

Эксперимент на лабораторных животных был проведен на базе ФГУ «Новосибирский научно-исследовательский институт травматологии и ортопедии» (ФГУ «ННИИТО Росмедтехнологии») на 40 крысах (мужского пола) линии Wistar, объединенных в группы-аналоги, в возрасте 4 месяцев со средней живой массой 240-250 г (табл. 1).

Таблииа 1

Схема эксперимента

\begin{tabular}{|c|c|c|}
\hline \multirow{2}{*}{ Группа } & \multicolumn{2}{|c|}{ Режим кормления, день эксперимента } \\
\cline { 2 - 3 } & $1-10$ & $11-42$ \\
\hline Контрольная & \multicolumn{2}{|c|}{ Основной рацион $(\mathrm{OP})$} \\
\hline 1-я опытная & \multirow{2}{*}{$\begin{array}{c}\text { OP }+15,0 \text { мг } \mathrm{Pb} / \text { кг массы }+ \\
+1,5 \text { мг Cd/кг массы }\end{array}$} & ОР \\
\cline { 1 - 1 } 2-я опытная & & ОР $+0,5$ мл экстракта с композицией 1 на 1 кг массы \\
\cline { 1 - 1 } 3-я опытная & & окракта с композицией 2 на 1 кг массы \\
\hline
\end{tabular}

Кормление крыс проводилось гранулированным кормом для лабораторных крыс и мышей «ПроКорм» (ГОСТ Р 50258-92), сбалансированным по содержанию питательных веществ, согласно нормам для данного вида животных. Животным обеспечивался свободный доступ к кормушкам и поилкам. Экстракты вводили животным per os. Опыт продолжался 42 дня.

Основные биохимические показатели: общий белок, кальций, холестерин, щелочную фосфатазу, мочевину - определяли фотоколориметрическими методами.

Анализ органов и тканей на содержание свинца и кадмия проведен методами, сертифицированными метрологической службой Госстандарата РФ. Токсиканты определяли по методикам, разработанным фирмой «Техноаналит ЛТД» и ТЦСМиС, прошедшим государственную сертификацию на приборе ТА-7 методом инверсионной вольтамперометрии [20].

Все полученные экспериментальные данные обрабатывали методом вариационной статистики и дисперсионного анализа на ПК с использованием пакета программ SNEDEKOR.

Введение в рацион крыс 15 мг свинца и 1,5 мг кадмия на 1 кг живой массы вызвало достоверное увеличение уровня свинца в органах и тканях лабораторных животных 1-й опытной группы. Так, в печени его концентрация возросла в 3,60 раза, в почках - в 11,00, в сердце - в 2,67, в селезенке - в 1,50, в мышечной ткани - в 3,50, в костной ткани - в 37,61 раза (P<0,01-0,001), в сравнении с показателями крыс, не получавших тяжелые металлы (табл. 2), что согласуется с ранее полученными результатами [14].

Применение экстрактов из лекарственного сырья привело к значительному уменьшению уровня свинца в органах и тканях крыс.

Так, введение в рацион крыс 2-й опытной группы экстракта с композицией 1 привело к снижению концентрации свинца в печени в 4,00 раза, в почках - в 1,17, в сердце - 3,00, в селезенке - в 2,40, в мышечной ткани - в 17,50, в костной ткани - в 3,89 (P<0,01-0,001) в сравнении с показателями крыс 1-й опытной группы, не получавших детоксиканта. 
Содержание свинца в органах и тканях лабораторных животных, мг/кг

\begin{tabular}{|c|c|c|c|c|}
\hline \multirow{2}{*}{$\begin{array}{l}\text { Органы } \\
\text { и ткани }\end{array}$} & \multicolumn{4}{|c|}{ Группа } \\
\hline & контрольная & 1-я опытная & 2-я опытная & 3-я опытная \\
\hline Печень & $0,010 \pm 0,002 * *$ & $0,036 \pm 0,004$ & $0,009 \pm 0,001 * *$ & $0,004 \pm 0,001 * * *$ \\
\hline Почки & $0,007 \pm 0,001 * * *$ & $0,077 \pm 0,004$ & $0,066 \pm 0,003$ & $0,059 \pm 0,004 * *$ \\
\hline Сердце & $0,009 \pm 0,001 * *$ & $0,024 \pm 0,002$ & $0,008 \pm 0,001 * *$ & $0,006 \pm 0,001 * *$ \\
\hline Селезенка & $0,008 \pm 0,001 * *$ & $0,012 \pm 0,002$ & $0,005 \pm 0,001 * * *$ & $0,002 \pm 0,001 * * *$ \\
\hline Мышечная ткань & $0,010 \pm 0,001 * * *$ & $0,035 \pm 0,002$ & $0,002 \pm 0,001 * * *$ & $0,009 \pm 0,001 * * *$ \\
\hline Костная ткань & $0,013 \pm 0,001 * * *$ & $0,489 \pm 0,018$ & $0,451 \pm 0,016$ & $0,418 \pm 0,009 * *$ \\
\hline
\end{tabular}

${ }^{* *} \mathrm{P}<0,01 ;{ }^{* *} \mathrm{P}<0,001$ (достоверно в сравнении с 1-й опытной группой).

Композиционный экстракт 2 в дозировке 0,5 мл на 1 кг живой массы вызвал уменьшение концентрации свинца в органах и тканях крыс 3-й опытной группы в печени в 9,00 раза, в почках - в 1,31, в сердце - в 4,00, в селезенке - в 6,00, в мышечной ткани - в 3,89, в костной ткани - в 1,17 (P<0,01-0,001) в сравнении с показателями крыс 1-й опытной группы, не получавших экстракта.

При введении в рацион тяжелых металлов произошло значительное увеличение концентрации кадмия во всех органах и тканях лабораторных животных 1-й опытной группы (табл. 3). Так, уровень кадмия в печени крыс возрос в 31,67 раза, в почках - в 25,31, в сердце - в 6,03, в селезенке - в 2,09, в мышечной ткани - в 2,47, в костной ткани - в 1,59 раза $(\mathrm{P}<0,05-0,001)$.

Таблица 3

Содержание кадмия в органах и тканях лабораторных животных, мг/кг

\begin{tabular}{|l|c|c|c|c|}
\hline \multirow{2}{*}{ Органы и ткани } & \multicolumn{4}{|c|}{ Группа } \\
\cline { 2 - 5 } & контрольная & 1 -я опытная & 2-я опытная & 3 -я опытная \\
\hline Печень & $0,0021 \pm 0,0003 * * *$ & $0,0665 \pm 0,0018$ & $0,0557 \pm 0,0022^{*}$ & $0,0477 \pm 0,0021 * * *$ \\
\hline Почки & $0,0061 \pm 0,0005 * * *$ & $0,1544 \pm 0,0116$ & $0,1075 \pm 0,0073 *$ & $0,0701 \pm 0,0041 * *$ \\
\hline Сердце & $0,0036 \pm 0,0005^{* * *}$ & $0,0217 \pm 0,0011$ & $0,0026 \pm 0,0004 * * *$ & $0,0017 \pm 0,0002 * * *$ \\
\hline Селезенка & $0,0023 \pm 0,0005^{*}$ & $0,0048 \pm 0,0006$ & $0,0022 \pm 0,0004 *$ & $0,0017 \pm 0,0003 * *$ \\
\hline Мышечная ткань & $0,0017 \pm 0,0003^{* *}$ & $0,0042 \pm 0,0005$ & $0,0018 \pm 0,0003 *$ & $0,0027 \pm 0,0004$ \\
\hline Костная ткань & $0,0017 \pm 0,0002$ & $0,0027 \pm 0,0004$ & $0,0018 \pm 0,0003$ & $0,0017 \pm 0,0002$ \\
\hline
\end{tabular}

${ }^{\star} \mathrm{P}<0,05 ;{ }^{* \star} \mathrm{P}<0,01 ;{ }^{* *} \mathrm{P}<0,001$ (достоверно в сравнении с 1-й опытной группой).

У крыс 2-й группы кадмий был обнаружен во всех внутренних органах, но его уровень в сравнении соответствующими значениями 1-й опытной группы был достоверно ниже. При введении в рацион 0,5 мл водно-спиртового экстракта с композицией 1 на 1 кг живой массы во внутренних органах лабораторных животных концентрация металла уменьшилась: в печени в 1,19 раза, в почках - в 1,44, в сердце - 8,34, в селезенке - в 2,18, в мышечной ткани - в 2,33, в костной ткани - в $1,50(\mathrm{P}<0,05-0,001)$.

Введение в рацион кормления крыс 3-й опытной группы экстракта с композицией «листья березы : хвоя сосны, $1: 1 »$ также привело к снижению уровня кадмия в органах и тканях животных. Концентрация металла уменьшилась в печени в 1,19 раза, в почках - в 2,20, в сердце в 12,76, в селезенке - в 2,82, в мышечной ткани - в 1,55, в костной ткани - в 1,59 (P<0,01-0,001).

О воздействии токсикантов на организм лабораторных животных в ходе эксперимента можно судить не только по накоплению и распределению свинца и кадмия в органах и тканях крыс, но и по показателям роста и развития (табл. 4).

Установлено, что у крыс, получавших с основным рационом соли свинца и кадмия, на конец эксперимента наблюдалось уменьшение живой массы на $10,22 \%(\mathrm{P}<0,05)$ в сравнении с животными контрольной группы. Показатель среднесуточного прироста (при расчете за пе- 
риод с 1-го по 42-е сутки опыта) у крыс 1-й опытной группы был на 30,48 \% ниже, чем у животных контрольной группы.

Таблица 4

Показатели роста и развития лабораторных животных, г

\begin{tabular}{|l|c|c|c|c|}
\hline \multirow{2}{*}{\multicolumn{1}{|c|}{ Показатель }} & \multicolumn{4}{|c|}{ Группы } \\
\cline { 2 - 5 } & контрольная & 1-я опытная & 2-я опытная & 3-я опытная \\
\hline Живая масса & $473,94 \pm 9,64$ & $425,48 \pm 11,61^{*}$ & $450,14 \pm 12,91$ & $463,11 \pm 14,28$ \\
\hline Среднесуточный прирост & 2,92 & 2,03 & 2,54 & 2,78 \\
\hline Сердце & $1,474 \pm 0,054$ & $1,411 \pm 0,060$ & $1,379 \pm 0,092$ & $1,339 \pm 0,045$ \\
\hline Печень & $20,464 \pm 1,479$ & $21,930 \pm 1,625$ & $22,463 \pm 1,229$ & $21,515 \pm 0,861$ \\
\hline Почки & $3,260 \pm 0,125$ & $3,686 \pm 0,118$ & $3,718 \pm 0,200$ & $3,748 \pm 0,173$ \\
\hline Селезенка & $1,142 \pm 0,029$ & $1,162 \pm 0,047$ & $1,077 \pm 0,038$ & $1,058 \pm 0,056$ \\
\hline
\end{tabular}

${ }^{\star} \mathrm{P}<0,05$ (достоверно в сравнении с контрольной группой).

В массе изученных внутренних органов у животных всех опытных групп достоверных отличий в сравнении с контрольной группой не выявлено.

Основным индикатором, раскрывающим картину метаболизма в организме животных, является кровь. Как одна из важнейших систем организма, она играет большую роль в его жизнедеятельности: кровь обеспечивает взаимосвязь обменных процессов, протекающих в различных органах и тканях, выполняет также защитную, транспортную, регуляторную, дыхательную, терморегулирующую и другие функции [21, 22].

Биохимический анализ сыворотки крови лабораторных животных показал, что в организме животных произошли достоверные изменения в результате кратковременной интоксикации свинцом и кадмием (табл. 5).

Таблица 5

Биохимические показатели

\begin{tabular}{|l|c|c|c|c|}
\hline \multirow{2}{*}{ Показатель крови } & \multicolumn{4}{|c|}{ Группы } \\
\cline { 2 - 5 } & контрольная & 1 -я опытная & 2-я опытная & 3-я опытная \\
\hline Общий белок, г/л & $73,00 \pm 1,00$ & $67,00 \pm 2,00^{*}$ & $70,00 \pm 1,00$ & $69,00 \pm 1,00$ \\
\hline Альбумин, г/л & $35,00 \pm 1,00$ & $29,00 \pm 2,00^{*}$ & $32,00 \pm 2,00$ & $30,00 \pm 1,00^{*}$ \\
\hline Мочевина, моль/л & $7,90 \pm 0,30$ & $6,50 \pm 0,20^{*}$ & $7,50 \pm 0,30$ & $7,20 \pm 0,20$ \\
\hline Глюкоза, ммоль/л & $6,52 \pm 0,30$ & $3,72 \pm 0,26^{* *}$ & $5,82 \pm 0,23$ & $4,98 \pm 0,39^{*}$ \\
\hline Холестерин, ммоль/л & $1,84 \pm 0,05$ & $2,22 \pm 0,07^{*}$ & $2,03 \pm 0,08$ & $2,12 \pm 0,12$ \\
\hline Кальций, ммоль/л & $2,94 \pm 0,15$ & $3,98 \pm 0,21^{*}$ & $3,46 \pm 0,06^{*}$ & $3,68 \pm 0,10^{*}$ \\
\hline Фосфор, ммоль/л & $1,73 \pm 0,11$ & $2,81 \pm 0,07^{* *}$ & $2,25 \pm 0,14$ & $2,48 \pm 0,10^{* *}$ \\
\hline
\end{tabular}

${ }^{\star} \mathrm{P}<0,05 ;{ }^{* \star} \mathrm{P}<0,01$ (достоверно в сравнении с контрольной группой).

Общий белок сыворотки представляет собой сумму всех циркулирующих белков и является основной составной частью крови. Определение общего белка используется в диагностике и лечении различных заболеваний, включая заболевания печени, почек, костного мозга, а также нарушений метаболизма и питания [21].

Концентрация общего белка в крови крыс 1-й опытной группы под влиянием токсикантов снизилась по сравнению с соответствующим показателем животных контрольной группы на $8,22 \%(\mathrm{P}<0,05)$.

У животных 2-й и 3-й опытных групп, получавших с основным рационом растительные экстракты, произошло незначительное уменьшение концентрации общего белка относительно животных контрольной группы на 4,1 и 5,5 \% соответственно, а по отношению к животным 1-й опытной группы - увеличение на 3,3-4,5\%. 
Альбумин представляет собой самую большую фракцию белков плазмы крови. Основными биологическими функциями альбумина являются поддержание онкотического давления плазмы, транспорт молекул и участие в метаболических процессах. Альбумин связывает и транспортирует билирубин, различные гормоны, жирные кислоты, ионы кальция, хлора, лекарственные вещества [21].

Снижение концентрации альбумина на 17,14 \% в крови наблюдалось у крыс в 1-й опытной группе, у животных в 3-й опытной группе - на 14,29 \% (P<0,05) относительно показателя интактных животных. Уровень альбумина в крови крыс 2-й опытной группы достоверно не отличался от этого показателя крыс контрольной группы.

Мочевина является низкомолекулярным соединением, свободно проходит через мембраны клеток паренхиматозных органов и эритроцитов. Концентрация мочевины в плазме зависит от скорости ее синтеза, клубочковой фильтрации и ренальной перфузии. Мочевина малотоксична, но токсичны накапливающиеся вместе с ней ионы калия и производные гуанидина. Концентрация мочевины в плазме часто используется как показатель функции гломерулярного аппарата почек. Снижение содержания мочевины в плазме происходит при нарушении синтетической функции печени, а также при потреблении малых количеств белков [22].

Снижение содержания мочевины наблюдалось в крови животных 1-й опытной группы на $17,72 \%(\mathrm{P}<0,05)$. Вследствие действия экстрактов у лабораторных животных 2-й и 3-й опытных групп его концентрация восстановилась до значения контрольной группы крыс. В сравнении с показателем у крыс 1-й опытной группы концентрация мочевины у животных в 3-й опытной группе увеличилась на 15,3\% (P<0,05).

Более 90 \% всех растворимых низкомолекулярных углеводов крови приходится на глюкозу. Глюкоза распределена практически равномерно между плазмой и эритроцитами, поэтому с равным успехом может определяться в цельной крови, плазме или сыворотке. Значения глюкозы в крови в течение дня непостоянны, зависят от мышечной активности, интервалов между приемами пищи и гормональной регуляции. При ряде патологических состояний нарушается регуляция уровня глюкозы в крови, что приводит к гипо- или гипергликемии. Измерение содержания глюкозы в крови является основным лабораторным тестом в диагностике, мониторинге лечения сахарного диабета, используется для диагностики других нарушений углеводного обмена [21, 22].

В результате скармливания опытным животным повышенных доз свинца и кадмия наблюдалось уменьшение концентрации глюкозы в сыворотке крови: в 1-й опытной группе на 42,9 \% $(\mathrm{P}<0,01)$, в 3-й - на 23,6 \%, что согласуется с нарушением функции печени и снижением уровня белка, а у крыс 2-й опытной группы содержание глюкозы увеличилось на 56,4 \% относительно животных 1-й опытной группы $(\mathrm{P}<0,01)$.

Холестерин является важнейшим показателем липидного обмена, служит структурным компонентом клеточных мембран, участвует в синтезе половых гормонов, желчных кислот, витамина D. Холестерин синтезируется в организме повсеместно и является необходимым компонентом клеточных мембран, входит в состав липопротеинов, является предшественником синтеза желчных кислот и стероидных гормонов [22].

Концентрация холестерина в сыворотке крови под влиянием тяжелых металлов увеличилась у крыс 1-й опытной группы на 17,12 \% (P<0,05) относительно показателя животных контрольной группы. Введение в рацион крыс 2-й и 3-й опытных групп композиционных экстрактов привело к нормализации уровня холестерина.

Минеральные вещества играют определяющую роль в поддержании кислотно-щелочного равновесия, осмотического давления клеточных и внеклеточных жидкостей, определяют состояние водно-солевого обмена, свертывающей системы крови, участвуют в мышечном сокращении, многочисленных ферментативных реакциях и т.д. Концентрация многих минеральных 
веществ в крови является существенным диагностическим признаком ряда заболеваний [21, 22].

Изучение уровня кальция используется для диагностики и лечения заболеваний паращитовидной железы, различных костных заболеваний, хронических заболеваний почек, мочекаменной болезни и тетании. Ионы кальция играют важную роль при передаче нервных импульсов, являются кофактором многих ферментов, необходимы для поддержания нормальной сократимости мышц и процесса свертывания крови.

Под влиянием кратковременной интоксикации содержание кальция в сыворотке крыс 1-й опытной группы увеличилось на 26,13 \%, 2-й - на 15,0, 3-й - на 20,1 \% (P<0,05) относительно показателя крыс контрольной группы. Вследствие действия детоксикантов у лабораторных животных 2-й и 3-й опытных групп наблюдалось снижение уровня кальция на 13,0 и 7,5 \% соответственно в сравнении с его содержанием в крови животных 1-й опытной группы. Причиной снижения кальция в крови могут быть почечная недостаточность, низкий уровень белка в крови, его вытеснение из обмена веществ путем замещения родственными элементами, в частности свинцом.

Диагностическое значение определения содержания в сыворотке крови неорганического фосфора велико, т.к. трудно назвать в организме физиологичную функцию, в осуществлении которой соединения фосфорной кислоты не принимают прямого или опосредованного участия.

Концентрация фосфора в сыворотке крови крыс по сравнению с контрольной группой достоверно увеличилась у животных 1-й опытной группы - на 38,43 \%, 2-й группы - на 23,1 \% $(\mathrm{P}<0,01)$. Уменьшение концентрации фосфора по отношению к показателю 1-й опытной группы произошло у животных в 3-й опытной группе - на 13,3% (P<0,05).

В результате изучения особенностей воздействия композиционных экстрактов лекарственных растений на организм лабораторных крыс в условиях кратковременной интоксикации свинцом и кадмием установлено:

1. Органы и ткани лабораторных животных обладают избирательностью в аккумуляции свинца.

2. Кратковременное поступление 15,00 мг свинца и 1,5 мг кадмия на 1 кг живой массы крыс вызвало увеличение уровня свинца и кадмия в органах и тканях.

Наблюдалась следующая закономерность в распределении свинца: костная ткань > почки $>$ печень > мышечная ткань > сердце > селезенка. Максимальное содержание свинца обнаружено в костной ткани, в сравнении с показателем крыс контрольной группы его концентрация возрастала до 37,61 раза. Уровень кадмия увеличивался в ряду: костная ткань < селезенка $<$ мышечная ткань < сердце < почки < печень - от 1,59 до 31,67 раза.

3. Применение композиционных экстрактов привело к снижению аккумуляции токсикантов в органах и тканях крыс. Добавление к рациону 0,5 мл на 1 кг живой массы экстракта с композицией «прополис : листья березы : хвоя сосны, $1: 1: 1 »$ вызвало снижение уровня свинца до 17,50, кадмия - до 8,34 раза. Экстракт, содержащий листья березы и хвою сосны (1 : 1), в дозировке 0,5 мл на 1 кг живой массы позволил снизить концентрацию свинца в органах и тканях крыс до 9,00, кадмия - до 12,76 раза.

Наибольшую детоксикационную способность в отношении свинца и кадмия проявил экстракт 2 .

4. Введение в рацион тяжелых металлов привело к достоверному уменьшению живой массы крыс на 10,22 \%, показателя среднесуточного прироста - на 30,48 \% в сравнении с животными контрольной группы.

5. Кратковременное поступление токсикантов привело к снижению содержания общего белка в сыворотке на 8,22 \%, альбумина - на 17,14, мочевины - на 17,72, глюкозы - на 42,9; 
концентрации холестерина, кальция и фосфора в сыворотке крови, напротив, увеличились на 17,$12 ; 26,13$ и $38,43 \%$ соответственно.

6. Использование водно-спиртовых экстрактов привело к частичной или полной нормализации биохимических показателей крыс, получавших тяжелые металлы. Добавление к рациону 0,5 мл на 1 кг живой массы экстракта с композицией 1 вызвало увеличение уровня общего белка на 3,3, глюкозы - на 56,4 \%. Экстракт, содержащий композицию 2, в дозировке 0,5 мл на 1 кг живой массы позволил повысить концентрацию общего белка на 4,5, мочевины - на $15,3 \%$.

Таким образом, проведенные исследования показали, что композиционные экстракты на основе прополиса, листьев березы и хвои сосны могут являться основой для разработки эффективного растительного препарата, используемого для профилактики и лечения животных от интоксикации солями тяжелых металлов.

\section{БИБЛИОГРАФИЧЕСКИЙ СПИСОК}

1. Бокова Т.И., Васильиова И.В., Коваль Ю.И. Оценка влияния сырья природного происхождения на содержание свинца и кадмия в модельных растворах // Инновации и продовольственная безопасность. - 2020. - № 1 (27). - С. 7-13.

2. Коноплева М.M. Продукты жизнедеятельности медоносной пчелы. Сообщение 2 // Вестник фармации. - 2011. - № 4 (54). - С. 82-94.

3. Коноплева М.M. Продукты жизнедеятельности медоносной пчелы. Сообщение $1 / /$ Вестник фармации. - 2011. - № 1 (51). - С. 76-86.

4. Хлгатян С.В., Бержеи В.М., Хлгатян Е.В. Прополис: состав, биологические свойства и аллергенная активность // Успехи современной биологии. - 2008. - Т. 128, № 1. - С. 77-88.

5. Вахонина Е.А., Будникова Н.В., Репьева Л.А. Прополис - источник флавоноидных соединений // Аписфера: научные достижения в пчеловодстве и апитерапии: сб. ст. I Всерос. науч.-практ. конф. - 2019. - С. 35-40.

6. Functional properties of honey, propolis, and royal jelly / M. Viuda-Martos, Y. Ruiz-Navajas, J. Fernández-López, J.A. Pérez-Alvarez // J. Food. Sci. - 2008. - N. 73 (9). - P. 117-124.

7. Суханова Л.В., Канарский А.В. Прополис как биологически активный продукт // Вестник Казанского технологического университета. - 2014. - Т. 17, № 4. - С. 198-203.

8. Protective effects of Chinese and Brazilian propolis treatment against hepatorenal lesion in diabetic rats / W. Zhu, Y.H. Li, M.L. Chen, F.L. Hu // Hum. Exp. Toxicol. - 2011. - Ser., 30 (9). P. 1246-1255.

9. Propolis attenuates cobalt induced-nephrotoxicity in adult rats and their progeny / M. Garoui el, A. Troudi, H. Fetoui [et al.] // Exp. Toxicol. Pathol. - 2012. - N. 64 (7-8). - P. 837-846.

10. Ярован Н.И., Ивлева Н.А., Долганова А.В. Прополис как средство адлаптогенного действия // Химические элементы - основа жизни: материалы Всерос. науч.-практ. конф. - 2020. С. 212-215.

11. Protective effect of caffeic acid phenethyl ester against cadmium-induced renal damage in mice / P. Gong, F. Chen, X. Liu [et al.] // J. Toxicol. Sci. - 2012. - N 37 (2). - P. 415-425.

12. Ведерников Д.Н., Рощзин В.И. Экстрактивные вещества листьев березы повислой Betula pendula Roth (Betulaceae). 1. Групповой состав, состав летучих соединений и кислот эфирных экстрактов // Химия растительного сырья. - 2012. - № 1. - С. 93-100.

13. Стеняева В.В., Куркин В.А. Сравнительное исследование флавоноидного состава листьев и почек березы бородавчатой // Сеченовский вестник. - 2016. - № S1. - C. 74-76. 
14. Васильиова И.В., Бокова Т.И. Возможность использования экстрактов растительного сырья в качестве биологически активных добавок // Инновации и продовольственная безопасность, 2015. - № 3 (9). - С. 5-10.

15. Флавоноиды лекарственных растений: прогноз антиоксидантной активности / В.А. Куркин, В.В. Поройков, А.В. Куркина, Е.В. Авдеева, О.Е. Правдивцева // Современные проблемы науки и образования. - 2015. - № 2-2. - С. 517.

16. Едремова Ю.Е., Винниикая В.Ф. Характеристика биохимического состава и пищевой ценности сырья для создания фруктовых и травяных чаев и напитков // Вестник Мичуринского государственного аграрного университета. - 2016. - № 1. - С. 104-108.

17. Анализ химического состава хвои ели европейской Picea / Е.М. Тарасова, С.Д. Хижняк, А.Ф. Мейсурова, П.М. Пахомов // Журнал прикладной спектроскопии. - 2019. - Т. 86, № 1. C. 96-102.

18. Торлопова Н.В., Робакидзе Е.А. Химический состав хвои сосны обыкновенной в условиях аэротехнологического загрязнения Сыктывкарского лесопромышленного комплекса // Сибирский экологический журнал. - 2012. - Т. 19, № 3. - С. 415-422.

19. Ярован Н.И., Северинова А.В., Полехина Н. Изучение антиоксидантных свойств хвои сосны и ели в модельной системе перекисного окисления липидов // Фундаментальные и прикладные исследования - сельскохозяйственному производству: сб. материалов VIII Междунар. науч.-практ. интернет-конф. - 2016. - С. 130-133.

20. ГОСТ 51301-99. Продукты пищевые и продовольственное сырье. Инверсионновольтамперометрические методы определения содержания токсических элементов $(\mathrm{Cd}, \mathrm{Pb}, \mathrm{Cu}$, Zn). - М.: Госстандарт России, 1999.

21. Наточин Ю.В., Немщов В.И., Эмануэль В.Л. Биохимия и диагностика крови. - СПб.: Клиническая больница РАН, 1993. - 149 с.

22. Гольдберг Е.Д. Справочник по гематологии с атласом микрофотограмм. - Томск, 1989. $369 \mathrm{c}$.

\section{REFERENCES}

1. Bokova T.I., Vasil'cova I.V., Koval' Yu.I. Innovacii i prodovol'stvennaya bezopasnost', 2020, No. 1 (27), pp. 7-13. (In Russ.)

2. Konopleva M.M. Vestnik farmacii, 2011, No. 4 (54), pp. 82-94. (In Russ.)

3. Konopleva M.M. Vestnik farmacii, 2011, No. 1 (51), pp. 76-86. (In Russ.)

4. Hlgatyan S.V., Berzhec V.M., Hlgatyan E.V. Uspekhi sovremennoj biologii, 2008, vol. 128, No. 1, pp. 77-88. (In Russ.)

5. Vahonina E.A., Budnikova N.V., Rep'eva L.A.Apisfera: nauchnye dostizheniya v pchelovodstve i apiterapii (Apisphere: scientific achievements in beekeeping and apitherapy), Proceedings of the Conference, 2019, pp. 35-40. (In Russ.)

6. Functional properties of honey, propolis, and royal jelly, M. Viuda-Martos, Y. Ruiz-Navajas, J. Fernández-López, J.A. Pérez-Alvarez, J. Food. Sci, 2008, No. 73 (9), pp. 117-124.

7. Suhanova L.V., Kanarskij A.V. Vestnik Kazanskogo tekhnologicheskogo universiteta, 2014, vol. 17, No. 4, pp. 198-203. (In Russ.)

8. Zhu W., Li Y.H., Chen M.L., Hu F.L. Protective effects of Chinese and Brazilian propolis treatment against hepatorenal lesion in diabetic rats, Hum. Exp. Toxicol, 2011, Ser. 30 (9), pp. 12461255.

9. Propolis attenuates cobalt induced-nephrotoxicity in adult rats and their progeny, M. Garoui el, A. Troudi, H. Fetoui, N. Soudani, T. Boudawara, N. Zeghal, Exp. Toxicol. Pathol, 2012, No. 64 (7-8), pp. 837-846. 
10. Yarovan N.I., Ivleva N.A., Dolganova A.V. Himicheskie elementy - osnova zhizni (Chemical elements are the basis of life), Proceeding of the All-Russian Scientific and Practical Conference, 2020, pp. 212-215. (In Russ.)

11. Pin Gong, Fuxin Chen, Xiaoying Liu, Xing Gong, Jing Wang, Yangmin Ma, Protective effect of caffeic acid phenethyl ester against cadmium-induced renal damage in mice, J. Toxicol. Sci, 2012, No. 37 (2), pp. 415-425.

12. Vedernikov D.N., Roshchin V.I. Himiya rastitel'nogo syr'ya, 2012, No. 1, pp. 93-100. (In Russ.)

13. Stenyaeva V.V., Kurkin V.A. Sechenovskij vestnik, 2016, No. S1, pp. 74-76. (In Russ.)

14. Vasil'cova I.V., Bokova T.I. Innovacii i prodovol'stvennaya bezopas-nost', 2015, No. 3 (9), pp. 5-10. (In Russ.)

15. Kurkin V.A., Porojkov V.V., Kurkina A.V., Avdeeva E.V., Pravdivceva O.E. Sovremennye problemy nauki i obrazovaniya, 2015, No. 2-2, p. 517. (In Russ.)

16. Efremova Yu.E., Vinnickaya V.F. Vestnik Michurinskogo gosudarstvennogo agrarnogo universiteta, 2016, No. 1, pp. 104-108. (In Russ.)

17. Tarasova E.M., Hizhnyak S.D., Mejsurova A.F., Pahomov P.M. Zhurnal prikladnoj spektroskopii, 2019, vol. 86, No. 1, pp. 96-102. (In Russ.)

18. Torlopova N.V., Robakidze E.A. Sibirskij ekologicheskij zhurnal, 2012. vol. 19, No. 3, pp. 415-422. (In Russ.)

19. Yarovan N.I., Severinova A.V., Polekhina N. Fundamental'nye i prikladnye issledovaniya sel'skohozyajstvennomu proizvodstvu (Fundamental and applied research - agricultural production), Proceeding of the VIII International Scientific and Practical Conference, 2016, pp. 130-133. (In Russ.)

20. GOST 51301-99. Produkty pishchevye i prodovol'stvennoe syr'e. Inversionnovol'tamperometricheskie metody opredeleniya soderzhaniya toksicheskih elementov $(\mathrm{Cd}, \mathrm{Pb}, \mathrm{Cu}$, Zn), Moscow, Gosstandart Rossii, 1999.

21. Natochin Yu.V., Nemcov V.I., Emanuel' V.L. Biohimiya i diagnostika krovi (Biochemistry and diagnostics of blood), St. Petersburg: Klinicheskaya bol'nica RAN, 1993,149 p.

22. Gol'dberg E.D. Spravochnik po gematologii s atlasom mikrofotogramm (Handbook of Hematology with an atlas of microphotograms), Tomsk, 1989, 369 p. 